\title{
EL LIBRO POR VENIR DE CHARLES BAUDELAIRE: «MAQUIAVELO Y CONDORCET» (COMENTARIO A DOS CARTAS A MADAME AUSPICK: DE 15-XI-1859 Y DE 8-XII-1859)
}

\author{
Charles Baudelaire's book to come: «Maquiavelo and Condorcet».
} Commentary on two letters to Mrs. Auspick (November 15, 1859 and

December 8, 1859)

\author{
Julián Sauquillo \\ Universidad Autónoma de Madrid
}

\begin{abstract}
RESUMEN: Charles Baudelaire manifestó su preferencia absoluta por la filosofía. A toda su obra le subyace un pensamiento católico. Su adscripción a tal línea reflexiva es intelectual y no religiosa o moral. Dentro del marco teológico de San Agustín, el poeta subraya la voluptuosidad del mal, se siente dominado por la acción de Satán. Nada hay más católico que el demonio, señaló. Desde esta perspectiva, su rechazo del progresismo es evidente. Los demócratas desean suprimir el infierno. Pero el «Pecado Original» se renueva cada mañana y nos condena al sacrificio y al dolor. Joseph de Maistre es uno de sus maestros de pensamiento. Es un maestro determinista en la historia, y monárquico y católico de convicción. Sin embargo, la llamada de Charles Baudelaire a una reflexión infinita sobre Maquiavelo, en las cartas a Mme. Auspick, abre un misterio insondable.

Palabras clave: Maquiavelo - Joseph de Maistre - Infierno - Spleen - democracia determinismo - número - sacrificio - Dios - San Agustín
\end{abstract}

Abstract: Charles Baudelaire stated his primary fondness for philosophy. Catholic thought, however, underlies all his oeuvre. His preference for such a reflexive position is neither religious nor moral but intellectual. Within the theological framework of Saint Augustine, the poet highlights the voluptuousness of evil while feeling governed by the action of Satan. Nothing is more Catholic than the devil, he pointed out. From this perspective, his rejection of progressivism is evident. Democrats want to suppress hell. But the «Original Sin» is renewed every morning and condemns us to sacrifice and pain. Joseph de Maistre is one of his master thinkers. He was a historical determinist, a vigorous monarchist and a committed Catholic. However, through his letters to Mme. Auspick, Charles Baudelaire's call for an endless reflection on Machiavelli, opened up an enigmatic mystery.

Keywords: Machiavelli - Joseph de Maistre - Hell - Spleen - democracy - determinism number - sacrifice - God - Saint Augustine

ESTUDIOS NIETZSCHE, 21 (2021), pp. 173-202. ISSN: 1578-6676.

(c) Sociedad Española de Estudios sobre Friedrich Nietzsche (SEDEN)

Recibido: 04-10-2021 Aceptado: 21-12-2021

Esta obra está bajo licencia internacional Creative Commons Reconocimiento-NoComercial-Compartirlgual 4.0. 
«Maistre es el Maquiavelo de la teocracia» E.M. Cioran, Essai sur la pensé réactionnaire. A propos de Joseph de Maistre (1977)

«Yo sé que reserváis una plaza al Poeta

En las filas dichosas de las santas Legiones, Y que le convidáis a la fiesta eternal de las Dominaciones, los Tronos, las Virtudes.»

“Bendición”, Las flores del mal $(1857,1861)$

\section{EL LIBRO POR VENIR: UN TRABAJO INFINITO PARA UN TIEMPO FINITO}

El libro Maquiavelo y Condorcet se quedó en una intención declarada a su madre como justificación familiar. Deseaba demostrarle su responsabilidad y resolución. Iba a ser escrito en el retiro más salvífico imaginado por el poeta frente a sus múltiples tribulaciones: la casa materna de Honfleur, una casa juguete junto a un acantilado. Debió concebirse en su imaginación como un diálogo -así figura en la cubierta de su Théophile Gautier (XI-1860). Se había interesado por un Diálogo en los infiernos entre Maquiavelo y Montesquieu de un abogado de París (Maurice Joly) del que había olvidado su nombre (Carta a Narcisse Ancelle, domingo 18-XII-1864) ${ }^{1}$. ¿Pudo influirle la amistad de su padre, François Baudelaire, con Condorcet ${ }^{2}$ en la elección del contrapunto de Maquiavelo? No lo sabremos. Nunca escribió semejante diálogo, pero no dejó de atribuir suma importancia al proyecto. Reiteró que le requeriría el sosiego de Honfleur y apuntó: «me llevará un tiempo infinito» («cela me tiendra un temps infini.») $)^{3}$. Tiempo de armonía del que nunca dispuso. Agrupar una reflexión en torno a un libro inexistente, como pretendo, en torno a un Maquiavelo abierto a un trabajo inacabable, inagotable, encierra un peligro: intentar resolver un enigma irresoluble. Pero toda creación es enigmática. Ignorarlo condena también al fracaso de partida. Detrás de toda obra escrita y publicada, existe una existencia literaria. La experiencia de la obra de arte posee una dimensión de

1 Charles Baudelaire, Correspondance (selección y presentación de Claude Pichois y Jérôme Thélot), París, Gallimard, 1973 (2000), 480 págs., pág. 311. Agradezco a Antonio Rincón Núñez sus valiosas aportaciones bibliográficas a este trabajo.

2 Théophile Gautier, «Baudelaire por Gautier», Baudelaire por Gautier, Gautier por Baudelaire, Madrid, Nostromo, 1974, 140 págs., 7-88, págs., pág. 24.

3 Charles Baudelaire, Oeuvres completes, Correspondance generale (recogida, clasificada y anotada por Jacques Crepet), Tomo II, 1857-1859, (recogida, clasificada y anotada por Jacques Crepet), Paris, Éditions Louis Canard, 1947, 409 págs., pág. 364, 372. 
pensamiento. Pero quien piensa es un hombre en una circunstancia. Observar a un autor a partir de un texto inexistente conduce a salirse parcialmente de su obra. Lleva a verle en la existencia del pensamiento. Requiere considerar algunas lecturas que subyacen a sus creaciones. Baudelaire alentó: «un gran libro sobre mí mismo, Mis confesiones» (A Mme. Auspick, 25-VIII-1861) ${ }^{4}$. Se miró al espejo de sus confesiones -los Diarios intimos- y tuvo presentes las confesiones de San Agustín y Thomas de Quincey, a quienes admiró, y JeanJacques Rousseau, a quien despreció ${ }^{5}$. Las propias cartas a Madame Auspick son una exhibición de las entrañas del poeta. Rodean puntualmente, con el rigor de la fecha, a dos «Diarios íntimos» del poeta a veces solamente apuntados: Cohetes (1851) y Mi corazón al desnudo (1864). Las cartas de Baudelaire son, en general, un memorial de la vida cotidiana del propio escritor en el tiempo en que no escribe su obra. Ya expuesto a los peligros de una obra que actúa como una potencia neutra, el escritor recoge detalles insignificantes. Registra obsesiones y necesidades por angustia a la soledad irreductible con su obra ${ }^{6}$. Las cartas a Madame Auspick recogen ese contexto a veces trágico, a veces trivial, de un libro futuro inexistente e importante. Sin embargo, el intento de acercarse al «libro por venir», al «campo literario» de Baudelaire, está condenado al fracaso 7 .

El diálogo entre Maquiavelo y Condorcet hubiera sido arrebatado y, por momentos, incandescente. Apunta, de partida, a un asunto político muy sugestivo: dos concepciones declaradas acerca de la posible conveniencia de engañar al pueblo. Condorcet representa la confianza ciega en que la instrucción y la ordenación racional -económica, social y política- de la democracia libraría a la especie humana de un embrutecimiento que sólo beneficiaba a sus gobernantes ${ }^{8}$. Maquiavelo es el partidario del engaño como único medio para conseguir la convivencia y, si cabe, la felicidad; la familia, la religión y el derecho (incluida la creencia en la «mandrágora» como excitante sexual) son meros instrumentos para que todos acaben contentos en La Mandrágora (1518). Además, Maquiavelo y Condorcet participan de dos filosofías de

4 Charles Baudelaire, Oeuvres completes, Correspondance generale, Op. Cit., Tomo III, 1860-septiembre de 1861, 352 págs., pág. 328.

5 En similar línea a Joseph de Maistre, Contre Rousseau. De l'état de nature, París, Mille et une Nuits (notas y postfacio Yannis Constantinidès), 2008, 95 págs..

6 Maurice Blanchot, L'espace littéraire, París, Gallimard, 1955, 379 págs., págs. 20-28.

7 Françoise Collin, Maurice Blanchot et la question de l'écriture, París, Gallimard, 1971 ( $2^{\mathrm{a}} \mathrm{ed}$. 1981), 256 págs..

8 Marqués de Condorcet, «Disertación filosófica y política o reflexión sobre esta cuestión: ¿es útil para los hombres ser engañados?», ¿Es conveniente engañar al pueblo? (Politica y filosofia en la Ilustración: el concurso de 1778 de la Real Academia de Ciencias de Berlín), Condorcet, Castillón, Becker (selección de textos, traducción y notas de Javier de Lucas), Madrid, Centro de Estudios Políticos y Constitucionales, 1991, 219 págs., págs. 181-219. 
la historia diferentes. Maquiavelo sostiene la idea del tiempo cíclico de nacimiento, maduración y corrupción inapelables -inspirado en Polibio y Tito Livio-, mientras que Condorcet supone la visión ilustrada, confiada en el progreso procurado por la especie humana y unas instituciones públicas bien ordenadas. La visión maquiaveliana desconfía de cualquier humanismo extensivo a todos y fía la regeneración del órgano colectivo a la voluntad del príncipe o de unos pocos. Mientras que la visión de Condorcet confía en que el progreso, las leyes y la razón se impongan sobre los vicios y las turbaciones de los hombres ${ }^{9}$. Locke y Voltaire se expresan dentro de semejantes valoraciones que el autor de Las flores del mal despreciaba. El atractivo filosófico, político y artístico de Maquiavelo para Charles Baudelaire no se explica por un supuesto republicanismo del florentino. Sí, indudablemente, por su atribución de poder a Uno. Su condición de profeta desarmado de la política, poeta, dramaturgo y autor de un sublime epistolario pudieron conmover a Charles Baudelaire. Maquiavelo era para Baudelaire la sensatez del sabio que ilumina como una columna luminosa el gran desierto de la historia ${ }^{10}$. Pero las coincidencias entre ambos no esconden una paradoja: Maquiavelo sólo es medianamente determinista: supone que el Príncipe virtuoso puede repartirse el juego con el destino ${ }^{11} \mathrm{y}$, además, era politeísta. Baudelaire leyó L'Histoire de la raison d'État de Giuseppe Ferrari (1860) y apreció imprescindible su prefacio. Con motivo de esta novedad editorial, se percató del distanciamiento de su autor respecto de Maquiavelo. Sobre todo, le llamó la atención que se atendiera a un posible pacto del Genio con el Destino. A Baudelaire le parecía insólita la soberbia de Genio capaz de examinar las leyes del Destino para «dejarle escapar de los vulgares goces de la vida, de las vanas consolaciones del Error.» (Carta a À Auguste Poulet-Malassis, Paris, en torno a 20-IV-1860) ${ }^{12}$. Que Baudelaire desprecia la visión histórica, política y científica de Condorcet requiere poca demostración. Pero que Baudelaire adquiera un compromiso de trabajo infinito con «Il Machia» es paradójico. Pudiera tratarse de una «boutade» propia del autor, pero no lo parece. Baudelaire reivindica el magisterio de San Agustín y Joseph de Maistre: monoteístas y deterministas. Maquiavelo no era tan determinista y era politeísta. Razón de más para que la admiración del poeta por el secretario florentino resulte extraña. Baudelaire pudo soñar un libro que

9 Catherine Kintzler, «Condorcet théoricien de la déclaration des Droits: une machine à éviter le crime», La philosophie et la Révolution Française (Bernard Burgeois y Jacques d'Hondt Drs.), París, J. Vrin, 1993, 309 págs., págs. 155-164.

10 Charles Baudelaire, «Edgar Poe, su vida y sus obras», Edgar Allan Poe (traducción de Carmen Santos), Madrid, La Balsa de la Medusa Visor, 1988, 124 págs., págs. 43-79, págs. 49, 50.

11 Nicolás Maquiavelo, El Príncipe (traducción y prólogo de Miguel Ángel Granada), Madrid, Alianza Editorial, 1981, 134 págs..

12 Charles Baudelaire, Correspondance, op. Cit., págs. 207, 208. 
nunca escribiría por alejado de sus posibilidades reales. Pero no imaginaba algo fuera de sus intereses. La reivindicación de un trabajo mayor para el futuro supone un punto de ruptura o de distanciamiento con el determinismo, el monismo y el clericalismo de sus maestros. Algo posible, perfectamente, porque estos católicos fueron queridos por Baudelaire no por inspirar una práctica religiosa católica sino como netos pensadores existenciales y políticos. Baudelaire pudo pensar un dominio estético, soberano, capaz de irradiar sobre las muchedumbres. No en vano, Baudelaire expande una poesía urbana que expresa el alma de la gran ciudad de París. Para Baudelaire, París es el campo de pruebas de la poesía en el pavimento de la calle. Incapaz de hacer vivir estéticamente a las muchedumbres, se mece, no obstante, en el movimiento de estas masas humanas. Sólo en la gran metrópolis pueden darse los grandes frutos espirituales ${ }^{13}$. Bien le valdría, entonces, el genio autosuficiente de Maquiavelo. Pudo concebir la política de un solo hombre que impusiera una Estética sobre la esclavitud de las profesiones y la crematística de su sociedad. Sería entonces menos nostálgico, menos culpable, más proactivo, más alegre y especialmente dominador sobre su época. Maquiavelo pudo alumbrarle la posibilidad de erigirse en Príncipe del Gusto en una sociedad en plena decadencia y miseria ${ }^{14}$. Si bien, el encuentro intelectual de Baudelaire y Maquiavelo es más radical: tiene al Diablo por mediador.

\section{EL «PECADO ORIGINAL», EN EL PERIÓDICO, CADA MAÑANA}

San Agustín, Maquiavelo, de Maistre y Baudelaire coinciden en tomarse el mal en serio. No fían su desaparición a la ordenación matemática del sufragio como Condorcet. Estos cuatro pensadores suponen que el crimen, la falta, el pecado serán tanto más hacederos para un individuo investido por las masas. Nietzsche transcribió y rehízo numerosos fragmentos de los escritos de Baudelaire. Los devoró como un poderoso lector que metaboliza todo aquello que le gusta ${ }^{15}$. Sabemos que Nietzsche apuntó en su cuaderno a comienzos de 1888 en Niza, para quedar consignada en los Fragmentos póstumos, una reflexión clave de Mon coeur mis à nu: «Teoría de la verdadera civilización.

13 Albert Thibaudet, «Baudelaire», Intérieurs, Baudelaire, Fromentin, Amiel, París, Plon, 1924, X+282 págs., págs. 1-61.

14 Danilo Kis considera a Baudelaire y Mallarmé habitantes de «las escarpadas y orgullosas alturas del esoterismo poético». Sin embargo, sostiene que Baudelaire fue el único, entre los poetas de su época, que, quizás, asumió «la tarea noble de crear una nueva sensibilidad» para educar al pueblo. Fracasaría por poseer una «voz demasiado sensible» y una «moraleja turbia y borrosa» según el escritor serbio. Danilo Kis, Homo poeticus. Ensayos y entrevistas (traducción de Luisa Fernanda Garrido y Tihomer Pistelek), Barcelona, El Acantilado, 319 págs., pág. 112.

15 Friedrich Nietzsche, Nachgelassene Fragmente (1885-1889) (Fragmentos póstumos, Volumen IV, 1885-1889, Edición dirigida por Sánchez Meca, traducción, introducción y notas de Juan Luis Vermal y Juan B. Linares, Madrid, Tecnos, 2006, 780 págs., págs. 412-426). 
No se da en el gas, ni en el vapor, ni en las mesas giratorias. Se da en la disminución de las huellas del pecado original» $(\mathrm{LX})^{16}$. Frente a las esperanzas redentoras del progresismo en la tierra, Nietzsche se complace, en esta ocasión, con una tradición católica que concibe al hombre como radicalmente culpable. Aún más, more agustiniano, consideró que la complicidad de las masas está presente en el origen del mal. Pero Nietzsche rompe con tal tradición al considerar la política como un «demonio» en necesaria tensión con el «dios del amor» cristiano. La confluencia de Nietzsche con el Maquiavelo soberanista que rige a la muchedumbre con la violencia necesaria es confesa. En el Crepúsculo de los ídolos, se mantiene la admiración maquiavélica por la crueldad de César Borgia, sin límite alguno de humana crueldad («Incursiones de un intempestivo», 37). Para Nietzsche, la lengua alemana nunca podría expresar el «aire seco y fino de Florencia», «los pensamientos, largos, pesados, duros, peligrosos, y el tempo, de galope y de óptimo y traviesísimo humor» de Maquiavelo (Más allá del bien y del mal, II, 28). El príncipe de Maquiavelo y la obra de Tucídides le condujeron a ver la razón en la realidad sin dejarse embaucar por el Ideal y, menos aún, por la moral («Lo que debo a los antiguos», 2, Crepúsculo de los ídolos). Charles Baudelaire despreciaba el librepensamiento de Diderot y Voltaire que el solitario de Sils-Maria apreciaba, desde Alemania, por haberse expresado en francés. Pero coinciden en encarar el mal sin paliativos ideales. Nietzsche y Baudelaire desean una «existencia ilimitada», ser el auténtico Señor. Si hay dos Dioses, se malicia Zaratustra, ¿Por qué no voy a ser yo el primero y auténtico Señor? La «sed de una vida sin límites», la «aspiración hacia el infinito», es propia de Baudelaire y Nietzsche. Son «apertura a la Total-potencia», tentación de ocupar la posición de Dios ${ }^{17}$. Dos demiurgos no pueden sino elevarse sobre toda criatura humana y, después, disputarse el primer puesto sobre la tierra. Ambos coinciden con Maquiavelo en una concepción soberanista de la política elevada sobre la opinión de la muchedumbre, conscientes del mal radical en que se origina la sociedad moderna. Y cabe que sea San Agustín quien se anticipe a sentar las bases del soberanismo bajo presupuestos católicos. Un soberanismo que persigue el pecado y el crimen (en su versión secularizada) y que no está más allá del bien y del mal sino en este duelo moral. Así es, porque el obispo es consciente de que el hombre está bajo el destino de la caritas y el rechazo de la cupiditas. Pero sabe que la caritas sólo origina una alianza de ángeles. El amor universal a todos sin distinción es amor a nadie en particular. Para él, tenemos una doble filiación. Somos hijos de Dios y beatíficos, e hijos de Adán, el primer pecador,

16 Se trata del fragmento póstumo 11 (160). Ibid. pág. 412.

17 Georges Blin, «La jalousie de la vie suffisante», Baudelaire. Suivi de Résumés des Cours au Collège de France, 1965-1977, París, Gallimard, 2011, 255 págs., págs.117-137. 
y condenados. La comunidad política sólo puede surgir de la persecución del pecado ${ }^{18}$. Se origina en la orden Compelle intrare («Obligadles a entrar») que oscila entre no encontrar límites, more maquiaveliano, y ejercerse dentro de los límites de la caridad cristiana. ¿De lado de quien se sitúa Baudelaire? ¿De la apostasía de Nietzsche o del pensamiento de San Agustín? No es fácil saberlo. Nietzsche y Baudelaire saben que el mal puede ser bello -aquí Las flores del mal- y desean transgredir lo sagrado ${ }^{19}$. Aunque la ontología de Baudelaire es católica y crítica con la escuela politeísta, su reivindicación de Maquiavelo simboliza su posición más allá del bien y dentro del mal. Sin embargo, la ligazón de Baudelaire con el catolicismo no se desata. El encuentro de Nietzsche con Baudelaire es dramático y musical ${ }^{20}$. Tras la escritura obsesiva del artículo de Baudelaire sobre Wagner, le sobreviene un abatimiento febril, el horror y el miedo (A Mme. Auspick, 1-IV-1861) ${ }^{21}$.

Las distancias y aproximaciones de Baudelaire con estas tradiciones filosóficas esclarecen su pensamiento fundamental porque confiesa abiertamente: «Adiós, y persuádase, como yo, más y más, de que la Filosofía es Todo.» (A Auguste Poulet-Malassis, París, sábado, 20-III-1852) ${ }^{22}$. A su padrastro le confiesa incluso su interés por «el estudio de la parte más bella de la filosofía, de la religión.» (Al Coronel Auspick, 26-II-1839) ${ }^{23}$. Baudelaire está entre los creadores que piensan y poseen un espíritu crítico ${ }^{24}$. No duda en señalarse seguidor de San Agustín y Joseph de Maistre. Destaca que este último le enseñó a pensar. Theophile Gautier y Hugo Ball coinciden en subrayar que tan buen latinista como Baudelaire admiraba el latín de la Iglesia, a Tertuliano y a San Agustín ${ }^{25}$. Hugo Ball recuerda, en concreto, que las asignaturas estudiadas por Baudelaire en la École des Chartres eran historia francesa y latín eclesiástico. Hasta tal punto le aprovechó a este buen latinista que compuso en latín eclesiástico «Franciscae meae laudes» en 1857,

18 Hannah Arendt, El concepto de amor en San Agustín (trad cast. y presentación de Agustín Serrano de Haro), Madrid, Encuentro, 2009, 150 págs..

19 Max Weber, «La ciencia como vocación», El político y el cientifico (traducción de Francisco Rubio Llorente, introducción de Raymond Aron), Madrid, Alianza Editorial, 1967 (7 e, d. 1981), 231 págs., págs. 174, 216.

20 Charles Baudelaire, «Richard Wagner et Tannhauser á Paris», Revue Européenne, 1 de abril de1861. (A Richard Wagner, viernes 17-II-1860) Charles Baudelaire, Oeuvres completes, Correspondance generale, op. cit., Tomo III, págs. 31-35. 264,265

21 Charles Baudelaire, Oeuvres completes, Correspondance generale, op. cit., Tomo III, págs.

22 Charles Baudelaire, Correspondance, op. cit., págs. 72.

23 Charles Baudelaire, Charles Baudelaire, Correspondance, op. cit., pág. pág. 45.

24 Albert Thibaudet, «Le cinquantenaire d'Alfred de Savigny», Réflexions sur la littérature, París, Gallimard, 2007, 1754 págs, págs.. 196-212, págs.. 200, 201.

25 Théophile Gautier, «Baudelaire por Gautier», Baudelaire por Gautier, Gautier por Baudelaire, op. cit., págs. 34, 35. 
dedicado a una modista culta y piadosa ${ }^{26}$. Pero el catolicismo no compromete su pensamiento y su actuación en la ciudad: no puede ser sino blasfemo al subrayar a Dios, que era Uno, como el principal culpable al crear la dualidad con Adán. El genio y el santo, como ideales del artista, buscan la soledad, atizan la guerra constante, son un cuerpoespín con los otros. «No cabe en mi afecto posible -señala- sin una cierta admiración.» (A Mme. Auspick, 25-XII$1861)^{27}$. Ni el genio ni el santo buscan la dualidad con el otro: «Cuando logre inspirar el asco y el horror universales -señala en Cohetes-, habré conquistado la soledad.» (XVII). Si el amor es una renuncia a uno mismo, pura prostitución, que no salva el abismo con el otro, Dios es el ser más envilecido: «El ser más prostituido es el ser por excelencia, Dios, -profiere en Mi corazón al desnudopuesto que es el amigo supremo de cada individuo, puesto que es el depósito común, inagotable del amor.» (XLVII) ${ }^{28}$. Baudelaire no esconde la rareza de su catolicismo: «La Teología. ¿Qué es la caída? Si es la unidad vuelta dualidad, quien ha caído es Dios. En otros términos- señala en idéntico lugar-: ¿no sería la creación la caída de Dios?» (XXXIV). Sin embargo, frente al ideario de 1848 y las negaciones del pecado original de Voltaire, Charles Baudelaire se confiesa católico convencido: señala tanto la irreductibilidad del mal como la fascinación de la masa por la autoridad en términos agustinianos. Baudelaire no cita a San Agustín para despistar ${ }^{29}$. El «Pecado Original» subyace como una moral, sin moralismo, tanto a su pensamiento como a su creación estética.

$\mathrm{Su}$ inmenso poemario «partía de una idea católica» (A Mme. Auspick, $1-\mathrm{IV}-1861)^{30}$. Una plaqueta representativa del «Pecado Original» serviría a una segunda edición de lujo de Las flores del mal. La idea le vino a Baudelaire hojeando l'Histoire des danses macabres de Hyacinthe Langlois y fue abandonada por la inclusión de un retrato del poeta ${ }^{31}$. En este trance de su existencia, Baudelaire retoma la reflexión sobre San Agustín con su editor Auguste Poulet-Malassis. Toda literatura nace del pecado y Langlois ha representado -le advierte- el esqueleto, las ramas, la serpiente, Adán,

26 Hugo Ball, La huida del tiempo (un diario) con el primer manifiesto dadaísta (prólogo de Paul Auster, presentación de Hermann Hesse, traducción de Roberto Bravo de la Vega), Barcelona, El Acantilado, 2005, 373 págs., pág. 90.

27 Charles Baudelaire, Oeuvres completes, Correspondance generale, op. cit, Tomo IV, Noviembre de 1861-1864, 350 págs., pág. 17.

28 Charles Baudelaire, Fusés. Mon coeur mi à un et autres fragments posthumes (édition d'André Guyaux), París, Gallimard, 2016, 2020, 463 págs.. Cito por la edición de Rafael Alberti de Charles Baudelaire «Mi corazón al desnudo», Diarios íntimos, México, La nave de los locos, 1981, 92 págs., págs. 41-92.

29 César González-Ruano, Baudelaire, Madrid, Espasa-Calpe, 1958, 233 págs., págs. 221-223.

30 Charles Baudelaire, Oeuvres completes, Correspondance generale, op. cit Tomo III, pág. 266.

31 Eugène Crépet y Jacques Crépet, Charles Baudelaire. Etude biographique, París, Librairie Léon Vanier Éditeur, 1906, 466 págs., págs. 141, 142. 
Eva, todo, inmejorablemente. En aquella coyuntura editorial, supone que la filosofía de la historia debiera expresar la lucha permanente y no la armonía eterna idealizada por la filosofía de $1848^{32}$. Ya habían pasado la admiración de Baudelaire por Proudhon y la fiebre insurreccional de junio de $1848^{33}$. Defendía, ahora, una cosmovisión pesimista de creación y destrucción sin apaciguamiento posible. La muerte y la destrucción de animales y razas se reemplaza por la creación de otras, de nuevo, en lucha -señala Baudelaire. La creación de Dios de la duración - apela Baudelaire a San Agustín- genera la lucha sin descanso en cada segundo (A Auguste Poulet-Malassis, París, VIII-1860) ${ }^{34}$. Toda la lucha destructiva -supone, en este sentido- no es sino el castigo eterno por un pecado cometido en el origen que se reaviva cada día. Baudelaire lo constata en su tiempo:

Todo periódico, de la primera línea a la última, no es más que una trama de horrores. Guerras, crímenes, impudicias, torturas, crímenes de príncipes, crímenes de naciones, crímenes de particulares, una borrachera de atrocidad universal- señala en Mi corazón al desnudo. Y es de ese aperitivo repugnante con lo que el hombre civilizado acompaña su comida de cada mañana. Todo, en este mundo, suda el crimen: el diario, la muralla y el rostro del hombre. No comprendo cómo una mano pura puede tocar un diario sin una convulsión de asco. (LXXXII).

Parece que leyera un periódico de nuestros días. Le bastaba abrir $L a$ Gazette des tribunaux para observar en los casos criminales el pecado original y la naturaleza caída del hombre. Baudelaire se revuelve contra el filántropo. Prefiere a las personas malignas, que saben lo que hacen, a las personas honradas y tontas (A Mme. Auspick, 9-I-1859) ${ }^{35}$. Supone que el crimen es natural desde el vientre de la madre. Y rebate a una tradición fraternal que concibe al crimen como efecto de las desigualdades, corregibles mediante una reforma de la sociedad, y no como un hecho natural ${ }^{36}$.

$\mathrm{Ni}$ los propios cristianos se toman en serio el «infierno». Quieren suprimirlo, como George Sand, -Baudelaire, se mofaba- por una deseable existencia indolora. Por ello, Baudelaire encuentra la reflexión sobre el mal en una tradición católica que lo combate pero está muy lejos de suponer posible

32 Dolf Oehler, Juin 1848, le spleen contre l'oubli. Baudelaire, Fliaubert, Heine, Herzen, Marx (traducido del alemán por Guy Petitdemange y Patrick Charbonneau), París, La Fabrique Éditions, 2017, 404 págs., págs. 23-122, 253-272, 274-333.

33 Claude Pichois, Jean Ziegler, Baudelaire (Pierrette Salas Martinelli), Valencia, Alfons el Magnànim, 1987, 783 págs., págs. 298-310.

34 Charles Baudelaire, Correspondance, op. cit., págs.. 224-227.

35 Charles Baudelaire, Oeuvres completes, Correspondance generale, op. cit., Tomo I, pág. 365.

36 Antoine Compagnon, Baudelaire l'irreductible, París, Champs, 2014, 335 págs., págs. 44, 45. 
su abolición. San Agustín y Joseph de Maistre sí revelan la insuperable existencia atormentada en la tierra como «Ciudad de los hombres». Existe una renovación diaria del pecado original, una tensión radical entre la «Ciudad de Dios» y la «Ciudad de los hombres» manifestada, de una parte, como paz y felicidad siempre con Dios; y, de la otra, como castigo eterno con el Diablo. La infelicidad sempiterna, el envilecimiento humano, la inefable presencia de la muerte, el inapelable castigo del hombre recto debido al pecado original, la inabordable conquista de la inmortalidad de los émulos de Dios, la propia querencia ciceroníana, la posibilidad de doscientas ochenta y ocho sectas posibles contra toda Unidad, la inefable presencia del diablo, la imposible redención de los vicios humanos en esta vida, o la propia decadencia propiciada por la soberbia, motivos tan agustianianos, no fueron ajenos al poeta. La dualidad de dos sociedades humanas - una destinada a vivir siempre con Dios, otra a sufrir castigo eterno con el diablo- y la ascesis de un hombre proveniente de la estirpe de Adán, que puede renacer hacia Cristo si prosigue su perfección, son telón de fondo de su vida mística, una actitud burlesca de la práctica ritual católica. Una anécdota ilustra esta creencia individual católica de Baudelaire no obediente a dogmas:

Un día un camarero me dijo, mientras me servía: “¿Va usted, pues, a la iglesia, señor? En Navidad, se le ha visto en tal iglesia”. Le respondí: “¡No digas nada de eso!" Pero me dije a mi mismo: "Se hablará de esto en el Consejo de Ministros". Dos días después, volví a encontrar a un belga que me dijo: “¡Ah! ¡Ya! ¡Entonces usted va a misa!” (...) “¿Qué hace usted en misa, si NO TIENE LIBRO DE LA MISA?" Este es un razonamiento esencialmente belga. No se reza sin libro. No se piensa sin reglamentos. (...)" (A Mme Paul Meurice, Bruselas, viernes, 3-II$1865)^{37}$

Baudelaire se dice a sí mismo en carta a su tutor legal -Narcisse Ancelle- que cuando esté absolutamente solo, buscará una religión (Tibetana o Japonesa), pues desprecia mucho al Korán, y, al momento de su muerte, abjurará de esta última religión adoptada para expresar lo mejor posible su aversión a la estupidez universal (A Narcisse Ancelle, Bruselas, 13-XI-1864) 38

Se da en Baudelaire un deseo constante de «higiene» espiritual, rotunda y contundentemente expresada en el descarnado balance de sus contemporáneos belgas. Baudelaire anhela la felicidad (de Honfleur) que siempre se aplaza. Pero la distancia purificadora con sus contemporáneos -bajo el insulto, la

37 Charles Baudelaire, Oeuvres completes, Correspondance generale, op. cit., Tomo V, 1865, 1866, 325 págs., pág 9 .

38 Charles Baudelaire, Oeuvres completes, Correspondance generale, op. cit., Tomo IV, pág. 330 
burla, el sarcasmo- se acompaña de la nostalgia de una armonía espiritual que nunca llega. Baudelaire es consciente de formar parte del infierno de los hombres y de la imposibilidad de redención. Ni las ilusiones editoriales, ni las remesas económicas de su madre, ni las estrategias abortadas para entrar en la Academia, ni un futuro de conferenciante, ni el escudo de una horda de amigos, ni la sabiduría antigua, alivian el gran infierno de los hombres. Baudelaire reconoce la superioridad agustiniana sobre el estoicismo al suponer desfachatez en considerar bienaventurada a una vida terrenal que aboca al suicidio como salida $^{39}$. Dice desdeñosamente en Cohetes: «El estoicismo, religión que no posee más que un sacramento: ¡el suicidio!» (XXI). Baudelaire no concibe eudemonismo alguno en medio de todos los males. Una alegría maternal le hubiera sido imposible de soportar (A Mme. Auspick, jueves, 11-IX-1856) ${ }^{40}$. Cualquier episódica felicidad le parece extraña: «Tuve tres días de alegre ocasión, siempre es algo ganado, es tan rara la alegría» (A Mme. Auspick, 27-II-1858) ${ }^{41}$. Cuando está contento, la alegría es amarga: «Por primera vez en mi vida, estoy casi contento. El libro está casi bien y quedará, este libro, como un testimonio de mi asco y de mi odio hacia todo.» (A Mme. Auspick, 1-I-1861 ${ }^{42}$. Se refería a Las flores del mal.

En aquel apunte de Niza, Nietzsche vio un rastro lúcido del pesimismo agustiniano. La vida pensada desde el pecado horrendo de Adán justificaba una vida penosa impedida para el progreso terrenal. Estamos condenados al eterno suplicio por la primera caída.

Un eterno suplicio parece inaceptable e injusto a la sensibilidad humana. La razón es que a nuestra pobre sensibilidad, abocada a morir, le falta aquel sentido de altísima e inmaculada sabiduría que nos capacita para percibir la enormidad del crimen cometido en la primera caída. En efecto, cuando más el hombre disfrutaba de la presencia de Dios, -señala San Agustín- tanto más enorme fue su impiedad al abandonarlo; se hizo acreedor a un mal eterno él, que en sí destruyó un bien llamado a ser eterno. De aquí parte el que todo el género humano se haya convertido en una masa condenada. (...). (Libro XI, «El fin de la ciudad terrena: el infierno», 12, La Ciudad de Dios) ${ }^{43}$.

De la ciudad celeste, desertaron los ángeles más soberbios. Hicieron uso

39 San Agustín, La Ciudad de Dios (Edición, estudio preliminar, selección de textos, notas y síntesis de Salvador Antuñano Alea), Madrid, Tecnos, 2007 (2 ed. 2010), 675 págs., págs. 402-405.

40 Charles Baudelaire, Oeuvres completes, Correspondance generale (recogida, clasificada y anotada por Jacques Crepet), Tomo I, 1833-1856, op. cit., p. 397.

41 Charles Baudelaire, Oeuvres completes, Correspondance generale, op. cit., Tomo II, pág. 148.

42 Charles Baudelaire, Oeuvres completes, Correspondance generale, op. cit., Tomo III, pág. 221.

43 San Agustín, La Ciudad de Dios, op. cit., págs. 453, 454. 
de su racionalidad y libre albedrío. Y, Dios, dentro del razonamiento bíblico de San Agustín, prefirió sacar bien de los mismos males que suprimir los males: para la rehabilitación de los pecadores, Cristo inocente sube a la cruz y los redime del pecado original ${ }^{44}$.

San Agustín anticipa la soledad del artista que Baudelaire pretende sin sosiego alguno: «Estoy solo, sin amigos, sin amante, sin perro y sin gato, $i^{\mathrm{a}}$ quién contarle mis penas? -señala el poeta. No tengo más que el retrato de mi padre, siempre mudo» (A Mme. Auspick, 6-V-1861) ${ }^{45}$. El santo acude a la poesía ficticia de las fábulas para referirse a Kakós, sin otro nombre sino Malo, en la «espantosa soledad de una caverna»: sin la dulzura de la esposa, sin hijo a quien enseñar, sin la amistosa conversación si quiera del padre. Deseoso de estar en paz con su cuerpo y que nadie le molestara, paciente de hambre e indigencia, salvaje y feroz como era Kakós, San Agustín no le da el crédito de «superhombre» nietzscheano, le otorga la dimensión de «semihombre». No le considera real. Si Caco hubiera existido careciera de los afectos de las ovejas, los ciervos, las palomas, los estorninos, las abejas, pero tendría, señala el obispo, al menos, las querencias de la zorra y el león, los animales queridos por Maquiavelo ${ }^{46}$.

La maldad caracterizada por San Agustín por la violencia, la soledad y la humana demasiado humana condición de Kakós revela algunos de los motivos de Charles Baudelaire. Fundamentalmente, expresa un ansia truncada de libertad y soledad. La Voluptuosidad, la Tristeza, la Melancolía, el Dolor componen la Belleza viril de Satán (Cohetes, XVI). Quizás el problema central del pathos de Baudelaire sea la conquista de la libertad frente a los otros, respondiendo a un Demonio interior. El poeta pretende la independencia frente a las muchedumbres: «[...] el mundo está hecho de gentes que sólo pueden pensar en común -señala desabrido-, en bandada. [...]. También hay gentes que no pueden divertirse más que en rebaño. El verdadero héroe se divierte solo.» (Mi corazón al desnudo, XVI). La prostitución es, para Baudelaire, dependencia (fraternal) de los demás. La más humillante y pesada dependencia del poeta, quizás, sea la tutela judicial del notario Ancelle sobre los bienes legítimamente heredados de su padre. Baudelaire fabula la violencia que genera la angustia de depender. El poeta pasa de la prostitución a la concentración creativa a duras penas. Así es porque la dependencia del tutor judicial, de los directores de periódicos, de los editores, de su propia madre le sitúa en un plano humanamente vulgar de dependencia económica. La dependencia es Mal que le encoleriza y sólo mediante la concentración evita su

44 Ibid., págs. 438, 467

45 Charles Baudelaire, Oeuvres completes, Correspondance generale, op. cit., Tomo III, pág 282

46 San Agustín, La Ciudad de Dios, op. cit., págs. 410, 411. 
instinto. Bascula entre la prostitución que le repugna y la violencia del ataque y la defensa. Por eso, Baudelaire oscila entre golpear y crear ${ }^{47}$. Los contactos corporales que Baudelaire recrea adquieren su turbulencia sanguinaria de la novela gótica, de la necrofilia y, de alguna manera, de los sacrificios de Sade. La cirugía del amor de la pareja, la ferocidad del cortejo animal, la embriaguez popular ante el suplicio del regicida Damiens, los puñales que emponzoñan con veneno la herida, las mordeduras corporales, las hemorragias de sangre que tiñen de rojo son mostradas estéticamente, por el poeta en Las flores del mal, como unión de Desenfreno y Muerte. Por muy metódicos que sean los golpes, su sadismo imaginario es revancha de su propio masoquismo. Se trata de una autoflagelación deleitable: «Quizás fuera dulce ser víctima y verdugo alternativamente», señala en Mi corazón al desnudo (III). El propio escarnio pone a prueba su dureza: «Hay pieles endurecidas -señala en Cohetes- con las cuales el desprecio no es ya una venganza» $(\mathrm{X})$, «Hay pieles endurecidas con las cuales el desprecio no es ya un placer» (XVII). También se infringe la propia humillación a los pies de todo lo malsano para ensalzar lo raro y deforme como lo más Bello ${ }^{48}$. Si bien esta Belleza monstruosa no trae sino el procesamiento y la general desaprobación de todos ${ }^{49}$.

La reflexión de San Agustin sobre el mal llega a plantear su belleza. Para el autor de la Ciudad de Dios, el universo sólo puede ser bello si abarca lo bueno y lo malo, de forma que las imperfecciones estén ordenadas para que destaque el bien sobre el mal ${ }^{50}$. La serie de violencias y tribulaciones de Las flores del mal serían tachadas de diabólicas por San Agustín. Pero la reflexión sobre el mal del santo tiene algo de inefable. El famoso robo de las peras cometido por San Agustín con una pandilla, que será objeto de su vergüenza en las Confesiones, es vano -las tenía mejores y fueron a los hocicos de los cerdos- y cobarde -se amparó en la irresponsabilidad del grupo ${ }^{51}$. Pero hacer el mal trivial es diferente de ser radicalmente malvado. El malvado no es banal, elige el mal para obtener algo atractivo. Roba por el agrado de lo robado y el propio encanto de la vida. La manifestación de su belleza se da por su correspondencia con cosas inferiores también bellas. Las cosas inferiores son bellas a su manera, poseen su belleza, aunque sean superadas por cosas superiores y de mayor belleza. El más malvado de los políticos romanos,

47 Charles Mauron, Le dernier Baudelaire, París, José Corti, 1966, 188 págs., págs. 114-116.

48 Georges Blin, El sadismo de Baudelaire (traducción de Luis María Todó), Barcelona, ediciones del subsuelo, 2021, 206 págs., págs. 13-55.

49 Rober Kopp, Baudelaire. Le soleil noir de la modernité, París, Gallimard, , 159 págs., págs. 65-91.

50 Gareth B. Matthews, Agustín (traducción de Roberto H. Bernet), Barcelona, Herder, 2006, 261, págs., pág. 200.

51 Vid. Lib.II, C. III, IV, V, VI, VII, VIII, IX, Lib. VII, C. II, III,IV,V, VII, San Agustín, Confesiones (Valentin M. Sánchez Ruiz), Madrid, 1942 (3 ${ }^{\mathrm{a}}$ d. 1958), 416 págs.. 
Catilina, se movía - dice el santo- por la atracción de objetos y bienes de inferior belleza. El más malo y cruel no obra de balde sino por algo valioso ${ }^{52}$. Ya sean «los cuerpos hermosos, como el oro, la plata y todos los demás» que «tienen cierta apariencia» ${ }^{53}$. Baudelaire no puede participar de un monismo católico que suponga la unidad de bien, belleza y verdad. Max Weber acierta en considerar Las flores del mal como ruptura de tal monismo: las más bellas pueden ser las más venenosas, como las más bienintencionadas pueden ser las más adormecedoras. Sin embargo, San Agustín ofrece una reflexión sobre la belleza del mal que impregna culturalmente siglos de catolicismo. También, se extiende por el mundo jesuítico en el que Baudelaire se forma.

La otra fuente del mal es la rebelión cuerpo a cuerpo contra el inexorable destino marcado por Dios, el desafio y la conquista de la divinidad. Si Dios traza nuestro destino calamitoso desde el pecado original, si decide cuando castigar a justos y pecadores por ser omnipotente y omnisciente, conquistar los cielos en la tierra requiere negar que seamos libres sólo dentro de los estrechos límites de lo decidido por él para nosotros. Baudelaire se llega a plantear sin contestar: «¿Qué es la libertad? ¿Puede concordar con la ley providencial?» Mi corazón al desnudo, XIV). Las dudas no se traducen en una confabulación. Aquí el Providencialismo subrayado por San Agustín y Joseph de Maistre identifica al pensamiento de Charles Baudelaire. Finalmente, Baudelaire no se rebela. Existe un gusto por la infelicidad que proviene de la impotencia, del fracaso, de la desproporción entre la realidad y el sueño, de la culpabilidad moral, ... en la expresión del poeta. Se da el anticlericalismo, las dudas filosóficas, las palabras descaradas contra lo santo, pero Baudelaire no encarna un grito de revuelta. Es capaz de las sensaciones más raras y peligrosas, su fortaleza es llamativa ${ }^{54}$, pero acepta la decadencia que sobreviene. Más que revuelta, hay lucha, conflicto y resignación. ${ }^{55}$

\section{LA EXCITACIÓN DE LA FURIA, LA MELANCOLÍA Y LA CONCIENCIA DE LA MUERTE}

El progresista moderno supone que en el origen fue la dispersión. De manera que la historia es un proceso en el que la dispersión se va concentrando, la multiplicidad adquiere forma unitaria. Para el cristiano, en cambio, al

52 Gareth B. Matthews, Agustín, op. cit. págs. 207-212.

53 San Agustín, Confesiones, op. cit., pág. 43.

54 Théophile Gautier, «Baudelaire por Gautier», Baudelaire por Gautier, Gautier por Baudelaire, op. cit., págs.. 8 y 18 .

55 Max Milner, Le Diable dans la littérature française de Cazotte a Baudelaire 1772-1861, Tomo II, París, Librairie José Corti, (segunda reimpresión, 1971), 578 págs., págs.. 437, 470. 
principio fue la unidad que se desgajó en lo múltiple hasta la llegada de Cristo que condujo lo confuso y múltiple de nuevo a lo unitario. El progresista sostiene que el desenvolvimiento de la historia requiere siempre el esfuerzo del hombre para superar el terror pánico, la sombría caverna, y alcanzar la razón. Para el cristianismo, en cambio, a la luz primitiva le sucedió la confusión y la multiplicidad. De Adán a Cristo, en la verdadera noche, Dios ha manifestado la revelación incompleta de la muerte temporal y la vida eterna de su Hijo al pueblo judío. Hasta la resurrección de Cristo, no hay sosiego sobre la tierra. La salvación está sólo en las manos de Dios (y no en la revolución). Dios omnipotente traza el destino inexorable de los hombres ${ }^{56}$. Esta concepción de la historia recorre todas Las veladas de San Petersburgo (1821) de Joseph de Maistre, para Charles Baudelaire intocable: «iY un hombre como usted soltando de paso, como un simple redactor de Le Siécle, injurias a de Maistre, el gran genio de nuestro tiempo! -escribe en la correspondencia-, ¡un vidente! [...]» (A Alphonse Toussenel, lunes 21-I-1856) ${ }^{57}$. En la cosmovisión de De Maistre, la Revolución Francesa no es un episodio espléndido en el avance de la especie humana. Es admirable por el rio sublime de sangre que deja y es temible por su pureza maléfica propia de la esencia del Mal. Algo que Baudelaire suscribe: «En todo cambio hay algo infame y agradable a la vez, -señala Baudelaire- algo que participa de la infidelidad y de la mudanza. Esto basta para explicar la Revolución Francesa.» (Mi corazón al desnudo, VIII). La Revolución responde a una lógica divina para De Maistre. Mientras que Baudelaire parece reconocer una mutación revolucionaria al designio de Dios. Sin embargo, ambos coinciden en lo fundamental: la providencia envió este castigo y renacimiento. El pecado original se repite de manera secundaria en cada instante actual. Para Baudelaire, el pecado original, evidentemente, es el pecado actual. La dimensión apocalíptica de la Revolución Francesa actualiza el Juicio final. De Maistre es un teólogo de la política que ve causas invisibles manifestadas visiblemente. La política experimental responde indefectiblemente a una metapolítica: la democracia es una ilusión ligada a una verdad revelada. Las decapitaciones de Luis XVI en Francia y de Carlos I en Inglaterra son expiaciones de las culpas de sus pueblos cara a su redención ${ }^{58}$. Baudelaire participa de estas concepciones «antimodernas». Le parece que la fantasía de la sangre de la revolución supera enormemente a todo el proceso de racionalización mecánica que traen los utopistas: «La mecánica nos habrá americanizado de tal modo, el progreso habrá atrofiado tanto en nosotros

56 José Ferrater Mora, Cuatro visiones de la historia universal, Madrid, Alianza Editorial, 1982,107 págs., págs. 32, 33, 38, 39.

57 Charles Baudelaire, Oeuvres completes, Correspondance generale, op. cit., Tomo I, pág. 369.

58 Antoine Compagnon, Les antimodernes de Joseph de Maistre à Roland Barthes, París, Gallimard, 2005, 464 págs., págs. 88-94, 107. 
toda la parte espiritual, que nada, entre las fantasías sanguinarias, sacrílegas o antinaturales de los utopistas, podrá compararse a sus resultados positivos.» (Cohetes, XXII). Y se mofa de la vulgaridad de los demócratas cuando advierte: «Por qué los demócratas no quieren a los gatos, es fácil de adivinar. El gato es hermoso: revela ideas de lujo, de limpieza, de voluptuosidad, etc.» (Cohetes, XIX). El gusto sublime se ha visto minado por la revolución burguesa, desde la perspectiva de todo el pensamiento antimoderno. Baudelaire es un revelador extraordinario y primero del desencantamiento del mundo moderno. No es extraño que Weber fuera uno de sus mejores lectores. La crítica del vaciado espiritual del proceso de racionalización moderno queda patente en sus reflexiones: «[...] Porque en el hombre hay cosas que se fortifican y prosperan a medida que otras se debilitan y empequeñecen; y, gracias al progreso de estos tiempos venideros, no quedaran de tus entrañas más que las vísceras. [...].» (Cohetes, XXII). La propia desaparición del «alma bella» aparece en sus escritos: «Dandysmo.- ¿Qué es el hombre superior? No es el especialista. Es el hombre de ocio y de educación general. Ser rico y amar el trabajo.» ( $M i$ corazón al desnudo, XXXIV). Baudelaire no es tanto un mero nostálgico del pasado como un crítico feroz de los tiempos modernos. Es el primero en ver cuáles serán los efectos anestesiantes de la modernidad.

De Maistre le enseñó a pensar también esta crítica de la modernidad. Charles Asselineau -biógrafo y gran amigo de Baudelaire hasta el final- nos proporciona una estampa cotidiana muy significativa de ambos. Están en la Rue de Rochefoucauld con el muy próximo Nadar, fotógrafo de Baudelaire a quién el poeta atribuía una vitalidad propia de un superhombre. Discuten sobre política y acerca de De Maistre, a quien el fotógrafo reconoce no haber leído y conocer por su propio contexto de vida. Baudelaire se enfureció al comprobar que Nadar desconocía la «refutación del sistema de Locke» realizada por De Maistre. El poeta interrumpió la conversación airadamente y le dio la espalda ${ }^{59}$. La anécdota es reveladora, aunque la actitud del poeta parece impostada. Es una incógnita por qué tal refutación se realiza estrictamente sobre bases metafísicas y ontológicas expresadas en el Ensayo sobre el entendimiento humano (1690) sin mención alguna a los dos Tratados sobre el gobierno civil (1690), ambos de Locke. Joseph De Maistre debiera haber confrontado adversativamente la refutación de Robert Filmer por Locke en el Primer tratado sobre el gobierno civil. El empirista inglés ataca a las monarquías hereditarias por una injustificada legitimación en la genealogía de las casas reales en Adán el primer rey. El Segundo tratado sobre el gobierno civil le sirve para fundamentar el gobierno en una instancia de apelación del pueblo

59 Charles Asselineau, «Baudelairiana. Colección de anécdotas», Charles Baudelaire. Su vida y su obra (edición y traducción Pere Rovira), Valencia, Pre-Textos, 156 págs., pág. 88. 
frente a la discrecionalidad de su monarca; y en la renuncia de la violencia privada en aras de la violencia pública fundada en un acuerdo de todos. Desde la justificación de la monarquía electa, Locke está avanzando las bases de un republicanismo democrático y de cierta concepción liberal posteriores. La propia difusión del pensamiento de Locke en Francia por Voltaire, tan despreciado por Baudelaire, se ciñe, lamentablemente, al Ensayo sobre el entendimiento humano ${ }^{60}$. Para De Maistre, hubiera sido un auténtico «tour de force» rebatir al Locke eminentemente político que discute a Adan como primer monarca y al Pecado Original. El empirista inglés había diseccionado las aseveraciones de Robert Filmer ${ }^{61}$ con los argumentos más sólidos y más ácidos. Locke es demoledor. Si Filmer nos dice unas veces que las formas de transferir la posesión de Adán son la donación y la sucesión, y otras señala que son la herencia, la usurpación y la cesión, porque le parece que lo relevante es el poder supremo y no cuales sean los medios para adueñarse de las coronas -señala Locke-, cabe el reinado de Sancho Panza si don Quijote hubiera enseñado a su leal escudero ${ }^{62}$. Joseph De Maistre pierde la ocasión de rebatir definitivamente la confianza política última de Locke en el pueblo dentro del Segundo tratado sobre el gobierno civil: los gobernantes y el monarca electo, en particular, poseen un poder fideicomisario («fiduciary Power», «fiduciary Trust») otorgado por el pueblo y podrían ser destituidos si menoscaban la confianza en ellos puesta ${ }^{63}$. De Maistre y Baudelaire son contrarios a la confianza de Locke en el pueblo. Joseph De Maistre se sitúa dentro de una concepción autoritaria del poder ${ }^{64}$. Y Charles Baudelaire, en semejante línea, poseía convicciones maquiavelianas: «Así, en política, el verdaderamente santo es aquel que fustiga y mata al pueblo por el bien del pueblo». (Cohetes, XII). Pero el argumento de De Maistre, frente a Locke, en Las Veladas de San Petersburgo, concretamente en la «Velada cuarta», se limita a rebatir el origen sensible de las ideas y a defender las ideas innatas. Pierde la ocasión de justificar el poder real en el «Pecado Original» y se introduce en una monótona discusión gnosológica. No pudo ser este el punto maistreano que separaba a Charles Baudelaire de su amigo Nadar tan contundentemente en materia política.

60 Voltaire, Lettres philosophiques (cronología y prefacio de René Pomeau), París, GarnierFlammarion, 1964, 188 págs., págs.82-88.

61 Robert Filmer, El Patriarca o el poder natural de los reyes (traducción y prólogo de Ángel Rivero), Madrid, Alianza Editorial, 2010, 184 págs..

62 John Locke, «Primer ensayo sobre el Gobierno civil», Dos ensayos sobre el gobierno civil (edición de Joaquín Abellán, traducción de Francisco Giménez Gracia), Madrid, Espasa Calpe, 1991, 389 págs., págs. 47-200, págs. 122-124.

63 Ibid. págs. 201-384.

64 Isaiah Berlin, Joseph de Maistre y los orígenes del fascismo (edición de Henry Hardy, traducción de Roberto Ramos Fontecoba), Barcelona, Página Indómita, 2021, 156 págs.. 
Baudelaire padecía la abominable vida que Joseph de Maistre achacaba a ser honesto en vez de un inconsecuente. En un lenguaje deliberadamente religioso, el poeta suponía, como el autor de Las veladas de San Petersburgo, que sobrevivía una parte divina del hombre creado a imagen de Dios, sobre los efectos del pecado original, hasta en los días deplorables que le tocó vivir. $\mathrm{La}$ influencia de De Maistre es patente en muchos sentidos. Su posición antimoderna encarna temor y fascinación por las innovaciones. Baudelaire consideró que los mismos artistas rechazados por la cultura antigua y marginados, refugiados en la fotografía, eran enviados por la providencia como agentes de castigo divino. Su férrea guardia frente a las novedades posee el resabio maistreniano. Ambos participan de una visión del mundo atravesada por la violencia sagrada. Tras la muerte de Abel por Caín, la eterna lucha fratricida contamina la sociedad humana. La consistencia de la violencia observada por Baudelaire en el tiempo presente, más allá de las ilusiones de fraternidad, son sumamente maistrenianas. En las Consideraciones sobre Francia (1796), Joseph de Maistre afirmaba ver sólo violencia en el universo, pese al engaño de la filosofía moderna que afirma que todo va bien. Charles Baudelaire consideraba a De Maistre el «gran genio de nuestro tiempo» por haber cuestionado el progreso infinito y señalado la violencia originaria ${ }^{65}$. El saboyano tuvo dos poderosas influencias en Baudelaire: una directa, la exaltación del temerario que confronta, que arremete sin sopesar matices y objeciones; la otra, invertida, pues retuerce los temas maistrenianos cuando el poeta invoca la «providencia diabólica» o profesa el «satanismo» ${ }^{66}$. Ambos comparten, del nacimiento a la muerte, la impresión cultural y estética de los jesuitas ${ }^{67}$.

Algunas de las influencias de Joseph de Maistre en Charles Baudelaire son desentrañadas por el Conde, el Senador y el Caballero en el diálogo de la «Velada octava». La teoría de los números les une en la convicción compartida de que la inteligencia divina sólo se muestra en su simetría numérica.

Dios nos ha dado el número, y por el número el hombre se evidencia a su semejante; quitad el número, y quitaréis las artes, las ciencias, la palabra y, por consiguiente, la inteligencia. Volved a traerle, y reaparecerán con él sus dos hijas celestiales, la armonía y la hermosura: el grito se convertirá en canto; el estrépito, en música; el salto, en danza; la fuerza se llamará dinámica, y los rasgos, figuras. ${ }^{68}$

65 Antoine Compagnon, Baudelaire l'irreductible, op. cit., págs. 63, 118, 132, 218, $226,227$.

66 E. M. Cioran, Ensayo sobre el pensamiento reaccionario. A propósito de Joseph de Maistre (traducción de Rafael Panizo), Barcelona, Montesinos, 2000, 206 págs., págs. 60-65.

67 Jean-Marc Vivenza, Maistre, Puiseaux, Éditios Pardès, 2003, 128 págs., págs. 12-14.

68 Joseph de Maistre, Las veladas de San Petersburgo (Prólogo de Rafael Conde), Madrid, Austral Espasa Calpe, 1943 (4a ed. 1998), 371 págs., pág. 284. 
El espejo de la inteligencia y el orden es el número; la inteligencia se complace en el número. El número es omnipresente y se refleja en la geometría del cielo. Es la voluntad del Legislador. Dentro del desorden total del mundo, se percibe -según De Maistre- el orden anterior. Salvo para ateos como Voltaire, existe un orden justo de las cosas bajo el imperio de $\operatorname{Dios}^{69}$. Baudelaire suscribe radicalmente esta teoría del número armónico cuando señala: «Todo es número. El número está en todo. El número está en el individuo. La embriaguez es un número.» (Cohetes, I). Que la Providencia ordena el mundo sólo es cuestionado por tanto sabio como ha proliferado en los tiempos actuales, señalan De Maistre y Baudelaire. Al poeta le cabe sumo desprecio a los científicos y académicos que se creen capaces de disponer el mundo a su antojo empírico. Ni la ciencia terrenal, ni la política de los hombres dirige al mundo. Frente al carácter disolvente de los filósofos, Joseph de Maistre y Baudelaire arremeten con la democracia y defienden un gobierno divino y aristocrático. Confluyen en la pregunta que el Conde se hace en la octava velada: «¿Por qué se ha cometido la imprudencia de conceder la palabra a todo el mundo? ${ }^{70}$. Baudelaire desacredita a una señora: «porque ha caído en la democracia como una mariposa en la gelatina» (A Édouard Manet, Bruselas, 28-X-1865) ${ }^{71}$.

Baudelaire comparte también con el genio saboyano la reversibilidad existencial. Somos justos y pecadores. Dios castiga a los justos y deja felices a los pecadores pues decide plenamente cuando nos castiga por faltas que seguro cometimos una y otra vez. Ambos desprecian la discusión de Voltaire y Rousseau en torno al terremoto de Lisboa de 1755. ¿Cómo pudo permitirlo un Dios bueno -se preguntan- si fue tan catastrófico?: o Dios es omnipotente pero no omnisciente (potente pero incapaz de su conocimiento previo para evitarlo) o Dios es omnisciente pero no omnipotente (inteligente pero incapaz de evitarlo $)^{72}$. La «Velada cuarta» rebate a los ateos ilustrados. Subraya que Dios es bueno, omnisciente, omnipotente y dueño de castigar a inocentes y culpables cuando desee, antes o después, por un Pecado Original que los hombres renuevan todos los días.

Se ha visto en la etimología de «pensar», del latín pendere, la reflexión como la utilización de los platillos de la balanza. Pensar es pesar y contar. De Maistre usaba esta polisemia antes que Baudelaire-según Antoine Compagnon. El número es principio de organización y armonía, capaz de ordenar el caos

69 Ibid. pág. 285.

70 Ibid. pág. 294.

71 Charles Baudelaire, Correspondance, op. cit., pág. 351. Charles Baudelaire, Oeuvres completes, Correspondance generale, op. cit., Tomo V, pág.165.

72 Jean-Jacques Rousseau, Cartas morales y otra correspondencia filosófica (edición de Roberto R. Aramayo), Madrid, Plaza y Valdés, Madrid, Plaza y Valdés, 2006, 365 págs.. 
en cosmos, el grito en canto, ... A Baudelaire le fascinaron las muchedumbres y la nueva ciudad por sus «innumerables relaciones» que desafían al número. Uno de los fragmentos herméticos de Mi corazón al desnudo se ha analizado dentro de la tensión entre armonía y caos:

Análisis de las contra-religiones: ejemplo la prostitución sagrada.

¿Qué es la prostitución sagrada?

Excitación nerviosa.

Mística del paganismo. El misticismo punto de enlace entre el paganismo y el cristianismo.

El paganismo y el cristianismo se demuestran recíprocamente,

La Revolución y el culto de la Razón demuestran la idea del sacrificio.

La superstición es el depósito de todas las verdades. (VII)

Es un fragmento enigmático que remite al principio de unión mística, la prisca theologia de Joseph de Maistre, nos señala Antoine Compagnon, quizás el mejor lector de Baudelaire. El hombre reconoce lo que tiene de más primitivo en la muchedumbre. A través de su maestro, Baudelaire observa la unión de cristianismo y paganismo en el fondo sacrificial de todas las religiones. En el sacrificio, se encuentran el dogma católico y los ritos paganos. El sacrificio y la redención son universales ${ }^{73}$. Cristianismo y paganismo se encuentran en la «reversibilidad» de los sacrificios, dogma universal de todas las creencias religiosas. O gran misterio del universo, tal como se denomina en la «Décima velada» de Las veladas de San Petersburgo ${ }^{74}$. La reversibilidad de los castigos de inocentes y culpables es una ley fundamental del mundo espiritual. El justo sufre no sólo por sí mismo sino también por los culpables. Es una verdad espiritual que explica todo, hasta donde se puede explicar, según De Maistre. Para Baudelaire, la prostitución moderna es una versión del sacrificio tradicional. La prostitución es para Baudelaire lo que el sacrificio es para Joseph de Maistre. Ambos comprenden el mundo a través de «sacrificio» y «prostitución». Para Baudelaire, el sacrificio de Cristo es una manifestación de la reversibilidad del mundo. Unión espiritual de la Iglesia con Cristo que, a su vez, se une con una prostituta (Carta de San Pablo a lo Corintios). La prostitución es sublimada por la unión espiritual ${ }^{75}$. La unión de amor y prostitución se observa en este fragmento de Cohetes:

Una vez preguntaron delante de mí en qué consistía el placer más grande del amor. Alguien respondió naturalmente: en recibir; y otro, en darse. -Aquel dijo:

73 Joseph de Maistre, Tratado sobre los sacrificios (traducción de María Tabuyo y Agustín López), Mdrid, sexto piso, 2009, 78 págs..

74 Antoine Compagnon, Baudelaire l'irreductible, op. cit., págs. 240, 241.

75 Ibid. 240, 241. 
placer de orgullo; -y este: voluptuosidad de humillación. Todos estos indecentes hablaban como la Imitación de Cristo. -Al fin, se encontró un impúdico que afirmó que el placer más grande del amor era el de formar ciudadanos para la patria. Pero yo digo: la voluptuosidad única y suprema del amor estriba en la certidumbre de hacer el mal. El hombre y la mujer saben, desde que nacen, que en el mal se halla toda la voluptuosidad. (IX).

Ni el sadomasoquismo del amor, ni el devocionario tan leído de Thomas de Kempis desde el siglo XV, ni la entrega a la patria satisfacen a Baudelaire: el sacrificio en el mal es la mayor voluptuosidad de Baudelaire.

Baudelaire invierte la dicha y la delicia que le provoca el bondadoso a Joseph de Maistre. De poco le vale, al poeta, la parsimonia bonachona de decir cada noche antes de dormir: «No he perdido el día». Ni la ausencia de miedos, ni la distancia con la vejez, ni el no padecimiento de zozobras devorantes, ni la posesión de energías renovadas para ser todavía mejor le complacen, más bien le irritan, a Baudelaire. Precisamente, le excitan más la furia, la melancolía, la conciencia de la muerte, el ensueño, las zozobras y la guerra intestina que el saboyano atribuye a Tiberio ${ }^{76}$. La parsimonia no es acicate para la creación. Baudelaire fomenta que le desprecien. Así se comprende el lanzamiento de su candidatura a la Academia francesa de imposible viabilidad. El poeta se extrañaba de que su amigo Manet no entienda que pintará mejor cuanto menos le entiendan y más le zahieran o desprecien (A Thóphile Thoré, 20-VI-1864; A Manet, jueves, 11-V-1865) $)^{77}$.

Lejos de apaciguar la guerra permanente terrenal, Joseph de Maistre ensalza el sacrificio de la guerra y subraya el carácter pluscuamperfecto del depredador humano. Existe un mundo invisible que explica toda matanza. Dios venga la iniquidad y exculpa las faltas a través de tales suplicios en la «Velada séptima». Nada depende más de Dios que las guerras productoras, debilitadoras o destructoras del poder del número. Y el Te Deum del Dios de los ejércitos es tanto de San Ambrosio como de San Agustín ${ }^{78}$. Baudelaire participa de esta visión sacrificial de la tradición católica. Señala en Mi corazón al desnudo: «Únicamente existen tres seres respetables: el sacerdote, el guerrero y el poeta. Saber, matar y crear. Los otros son tallables y curvables, hechos para la cuadra, es decir, para ejercer lo que se llaman las profesiones.» (XXIII). Para De Maistre, los griegos no hicieron expiaciones, nunca estuvieron contritos. El lenguaje de crimen y criminal es de todas las lenguas, la del pecado y los pecadores es cristiana y judía. Para De Maistre, las lenguas del Libro de los

76 Joseph de Maistre, Las veladas de San Petersburgo, op. cit., pag. 119.

77 Charles Baudelaire, Oeuvres completes, Correspondance generale, op. cit., Tomo IV, págs. 275-277, Tomo V, 95-97.

78 Joseph de Maistre, Las veladas de San Petersburgo, op. cit., págs. 254, 255. 
Salmos, Libro por excelencia, son el hebreo y el latín, lenguas de súplica. La Antigüedad no es una tradición del sacrifico y de la virtud concebida como obediencia a Dios. Tampoco lo son las tesis favoritas del siglo XVIII ${ }^{79}$. El lenguaje de los sacrificios de Cristo y demás inocentes por la redención de los culpables es católico ${ }^{80}$

Precisamente en el lenguaje del sacrificio se encuentran las tareas del Príncipe de Maquiavelo y del Poeta de Baudelaire. Afrontar la conservación del poder inmanente requiere sacrificar la teología, los intereses del Cielo, a los realia de la política ${ }^{81}$. Apenas importa la más preciada declaración de determinismo de De Maistre -el genio de Baudelaire-. Poco relevante es que sea capaz de encuadrar el humano libre albedrío en el mayor designio de Dios y dejar al hombre un mero obrar mecánico ${ }^{82}$. ¿Qué importa que Maquiavelo se declare sólo medianamente determinista? De Maistre obvia esta diferencia con Maquiavelo. Considera a este «gran político y ardiente republicano» el impulsor de la concentración de poder en uno solo, dado que el pueblo no es capaz de sostener su episódica libertad ${ }^{83}$. Pinta piadoso al autor de El Príncipe (1513-1516), comparado con la insania de Voltaire que admira el vicio ${ }^{84}$. Pero el saboyano se declara adversario de algunas de las tesis maquiavelianas más firmes: las que señalan que el poder y la grandeza corrompen al hombre y que los mejores reyes han sido los que la adversidad puso a prueba ${ }^{85}$. Incluso, nunca aprobaría la política politeista que representa «Il Machia»: para De Maistre, la jerarquía del poder es encabezada por el poder espiritual sobre el poder temporal (el Papa es guardián del cumplimiento de las leyes fundamentales del Estado por los soberanos $)^{86}$. La religión católica es el elemento constitutivo de la «Monarquía europea» ${ }^{87}$. Sin embargo, el consejero florentino y el poeta convergen en el sacrificio del Mal y la posible redención de todos. Los Capítulos XVII y XVIII del Libro I de los Discursos sobre la

79 Ibid, págs. 256, 257, 259,261, 262.

80 Ibid. pág. 304, 305.

81 Pierre Glaudes, «Machiavel, Nicolas (1469-1527»), «Dictionnaire», Joseph de Maistre, Oeuvres, París, Robert Laffont, 2007, 1348 págs., págs. 1115-1310, pág. 1218.

82 Ibid. pág. 250.

83 Joseph de Maistre, Consideraciones sobre Francia (estudio introductorio de María Luis Guerrero Alonso, traducción Alejandro García Mayo), Madrid, Escolar y Mayo, 2015, 196 págs., págs. 107, 108 y 128.

84 Ibid. pág. 135.

85 Ibid. pág. 131.

86 Joseph de Maistre, «Del Papa», El mayor enemigo de Europa y otros textos escogidos (Antología y presentación de E. M. Cioran, traducción de Yolanda Morató), España, el paseo, 2020, 259 págs., págs. $56-111$.

87 Luis Gonzalo Díez, Anatomía del intelectual reaccionario: Joseph de Maistre, Vilfredo Pareto y Carl Schmitt. La metamorfosis fascista del conservadurismo, Madrid, Editorial Biblioteca Nueva, 2007, 364 págs., pág. 209. 
primera década de Tito Livio (1515-1518) presentan al hombre excepcional como el único capaz de regenerar la corrupción de la república mediante las más duras metamorfosis:

[...]. Y como el reconducir una ciudad a una verdadera vida política presupone un hombre bueno, y volverse, por la violencia, príncipe de una ciudad presupone uno malo, sucederá muchísimas veces que un hombre bueno quiera llegar a ser príncipe por malos caminos, aunque su fin sea bueno, o que un hombre malo que se ha convertido en príncipe quiera obrar bien, y le quepa en la cabeza emplear para el bien aquella autoridad que ha conquistado con el mal. [... $]^{88}$

El príncipe soporta los pesos más pesados para restablecer la fisonomía de la república y sacarla de su infierno inevitable. El príncipe conoce muy bien los defectos de los hombres: perdonamos antes la calumnia a nuestros padres que se nos retraigan los propios bienes para fines colectivos, somos traidores, respetamos más al que nos causa temor que al que nos profesa amor, nos vengamos de quien odiamos con ocasión de traicionarle. El príncipe está rodeado de múltiples Judas ávidos de confabulaciones y traiciones. Y, como se observó en el barroco español, se acaba percibiendo la traición cuando ya se padece el calvario a la manera de Cristo $^{89}$.

Baudelaire participa intelectualmente de la filosofía de la historia y el marco teológico político de Joseph de Maistre, pero invierte su orden de valores. El satanismo que aparece con Baudelaire no es tomado de Joseph de Maistre, que ignora a Satán. Ni la exaltación de la carne para humillar al espíritu caído, ni la mofa de la conciencia ante la inanidad de los esfuerzos, que dan forma al satanismo, son considerados alguna vez por el saboyano ${ }^{90}$. El satanismo supone una inversión valorativa de Baudelaire a los presupuestos católicos de su maestro. En cambio, el encuentro de Baudelaire y Maquiavelo es directamente diabólico. La obra narrativa más conocida del florentino, la Fábula del archidiablo Belfagor (1518), reivindica el ejemplo del demonio. Representa una inversión de la tradición católica del «ejemplo» (el «exempla» medieval para la predicación) dado en la prédica a través de la parodia: ofrecer al diablo como ejemplo es parodia blasfema de la tradición ejemplar. El ejemplo no es el campesino Gianmatteo sino el mismísimo Belfagor, bajo el nombre de Rodrigo de Castilla, comisionado por los jueces del Averno para

88 Nicolás Maquiavelo. Discursos sobre la primera década de Tito Livio (introducción, traducción y notas de Ana Martínez Arancón), Madrid, Alianza Editorial, 1987, 435 págs., pág. 86.

89 Julián Sauquillo, «Providencia y Poder pastoral en el Príncipe cristiano de Quevedo», Horizontes de la Filosofia del Derecho. Homenaje al Profesor Luis García San Miguel (III) (Virgilio Zapatero, Ed.), Alcalá de Henares, Universidad de Alcalá, 2002, 805 págs., págs. 707-736.

90 Daniel Vouga, Baudelaire et Joseph de Maistre, París, Librairie José Corti, 1957, 219 págs., pág. 151. 
indagar, en la tierra, la causa de tantos pecadores. Tanto para Baudelaire como para el escritor de este cuento, la mujer es causa del descenso a los infiernos. Haber tomado esposa sería, para ambos, la causa de corrupción (o prostitución amorosa en expresión del poeta) que Belfegor debe investigar en el infierno terrenal. El diabólico comisionado salta hacia arriba para observar el infierno terrenal diario y verificar su pobreza, prisión, enfermedad y demás miserias. Tras comprobar los oprobios e insanias del infierno terrenal, Belfegor, investido de Rodrigo de Castilla, regresa muy amedrentado al Infierno no fuera que regrese su esposa ${ }^{91}$. Para ambos autores, la mujer es la encarnación del diablo disfrazado. En Baudelaire se ha observado la encarnación de las fuerzas satánicas en su interior, una providencia luciferina, y ningún propósito rebelde contra la divinidad. Disposición maléfica que le condujo a la soledad, la melancolía, la tristeza y la nostalgia de una armonía que nunca llega ${ }^{92}$. Un pathos bien semejante al de Maquiavelo que, defenestrado del poder, anhela el retorno al poder, los ornatos y la suficiencia de una vida grata que no retorna. El florentino reserva la actitud rebelde respecto del papado a Savonarola, desde la distancia del cínico y reservado con el ingenuo y auténtico. Baudelaire tampoco alienta rebeldía alguna: responde al designio del diablo. El mundo intelectual de Maquiavelo le aporta a Baudelaire la alianza directa con la manipulación del Mal que Joseph de Maistre sólo expresa indirectamente.

La presencia del Diablo en la obra de Baudelaire es permanente. Se manifiesta tanto como una fuerza exterior como una presencia íntima. Se siente íntimamente mezclado con Satán, se baña en su fondo maléfico. Baudelaire desea tanto la exaltación blasfema del mal por el mal como la protesta herética contra las limitaciones de la condición humana. Pero, ¿cuál es el origen de su encarnación con el mal? Por encima de su origen católico, se ha destacado el origen perverso del mal en sus escritos. De una parte, su vinculación con la tradición del pecado original recoge ciertos temas católicos. No existe nada más católico que el Diablo y nada más subversivo para dicha tradición. En Baudelaire, se daría una adhesión intelectual a un credo. Se presenta una pregnancia católica y la herejía consiste en que elige entre unos y otros temas de esta tradición religiosa en vez de acatar el dogma. Falsea, entonces, el sentido católico del Diablo en el drama religioso del Calvario. A diferencia del católico que cuenta con las fuerzas divinas en el drama entre Dios y Satán, él se siente abandonado a sus propias fuerzas. Pero cabe que esta visión cristiana sea insuficiente. De parte más profunda, algunos ven una trasmutación creativa satánica. Quizás su sentimiento primitivo satánico se manifiesta, más

91 Nicolás Maquiavelo, Fábula del archidiablo Belfagor (traducción, estudio y notas de José Abad), Granada, Ediciones Traspiés, 2011, 81 págs..

92 Jean Starobinski, La mélancolie au miroir. Trois lectures de Baudelaire, París, Julliard, 1997, 94 págs.. 
profundamente, en el gusto del infinito de los Paraísos artificiales (1860): el horror y el éxtasis de la vida son las dos caras de la misma actitud. El horror hacia la vida se debe a que la existencia no se hermana con el sueño. El éxtasis es conexión con la naturaleza violenta y facilitadora del descenso. La prohibición posee el atractivo del precipicio ${ }^{93}$.

$\mathrm{Su}$ particular y poco ortodoxa interpretación del pecado original -signo decisivo de la presencia de Satán- posee, en esta segunda visión, otro correlato muy diverso al católico: la perversidad de Poe ${ }^{94}$. «De Maistre y Edgar Poe me han enseñado a razonar», señala en Mi corazón al desnudo (XC). El Poe de Baudelaire no incurre en la tradición católica. Realiza una exaltación del hombre natural no sometido a medida ordinaria. Aunque al hombre salvaje le sea inconcebible la «idea de un poder espiritual y supremo», la comparación del hombre civilizado con el salvaje -señala Baudelaire en su análisis de Poeotorga todo el honor a este. Baudelaire introduce a Poe en Francia como al amigo que desecha el progreso y defiende a un hombre enciclopédico, mezcla de esposo, guerrero, poeta, sacerdote, mago, médico y dandi. El salvaje es el «dandy» ${ }^{95}$ que refuta al «guardia municipal de la opinión» tan dado a difamar al «hombre de letras» ${ }^{96}$. En él, Baudelaire encuentra la otra justificación del mal como perversidad:

[...] ha visto claramente, ha afirmado imperturbablemente, la maldad natural del hombre. Hay en el hombre, dice, una fuerza misteriosa que la moderna filosofía no quiere tomar en consideración [...]. Esa fuerza primitiva, irresistible, es la Perversidad natural, que hace del hombre, siempre y simultáneamente, homicida y suicida, asesino y verdugo; pues -añade, con una sutileza notoriamente satánica- la imposibilidad de encontrar un motivo razonable suficiente para determinadas acciones malvadas y peligrosas, podría llevarnos a considerarlas como sugestiones del Diablo, si la experiencia y la historia no nos enseñaran que Dios a menudo consigue el establecimiento del orden y el castigo de los tunantes: jtras haberse servido de los mismos tunantes como cómplices! Esto es lo que se desliza, lo confieso, en mi mente, como sobreentendido tan pérfido como inevitable. [... $]^{\prime 99}$.

La admiración de Baudelaire por este autor que piensa como él, pero con la genialidad de anticipársele veinte años, es manifiesta, es patente. Baudelaire

93 Max Milner, Le Diable dans la littérature française de Cazotte a Baudelaire 1772-1861, Tomo II, op. cit., págs. 435, 437, 439, 445-448, 449, 453, 454, 455, 457, 458.

94 Ibid. pág. 459.

95 Félix de Azúa, Baudelaire y el artista de la vida moderna, Pamplona, Pamiela, 1991, 169 págs..

96 Charles Baudelaire, «Nuevas notas sobre Edgar Poe», Edgar Allan Poe, op. cit., págs. 92-95.

97 Ibid. págs. $88,89$. 
le lee, le traduce, le edita como alma gemela muy cercana. Sin embargo, parece supeditarle finalmente a la tesis agustiniana y maistriniana de que Dios se sirve del mal, no lo evita, para hacer el bien. No obstante, la visión del Dandy y la admonición sobre el tedio (Spleen), como nuevo pecado mundano de la sociedad moderna, es coincidente con Poe ${ }^{98}$.

\section{EL «MARTIROLOGIO DE LA LITERATURA»}

Baudelaire observa al alma provisora en la madre de Poe, que le defiende de la adversidad. Es el alma heroica sin cuya abnegación y reconocimiento el «martirologio de la literatura» sería tanto más descarnado ${ }^{99}$. Su propia madre es trasunto de esa mujer que ayuda al poeta norteamericano más allá de su pronta desaparición. Las cartas a Madame Auspick -donde se inscribe su laborioso interés por Maquiavelo- son el relato del calvario del poeta y su deseo de redención imposible. Las cartas no reflejan el progreso literario de un escritor en estado de gracia. La escritura de Baudelaire también está bajo el pecado original de todos. Théophile Gautier subraya el desprecio de Baudelaire por cualquier suerte de filántropos que aspiren a cambiar la naturaleza perversa y el curso fatal de las sociedades. El pecado original está presente en esta turbia naturaleza. Hacemos lo que nos resulte funesto y perverso por ansia rebelde de contravenir la ley de Dios. Lejos de ser un inmoralista, Baudelaire castigaba este fondo perverso tanto en los demás como en sí mismo. Siempre, como si el castigo lo realizara un esclavo sorprendido en flagrante delito. En el fondo, carecía de propósito redentor en su rigor consigo mismo porque lo consideraba inútil ${ }^{100}$. El pecado de Baudelaire en la escritura era el aplazamiento -la procrastinación señalada por Max Milner ${ }^{101}$-; el tormento son las deudas, principal y letalmente, con un chatarrero y anticuario; el cautiverio es la administración judicial de la herencia por el notario Ancelle; el calvario es la sucesión inacabable de domicilios; la confesión son las cartas a Madame Auspick; la nostalgia de regreso al paraíso perdido es la llegada aplazada a Honfleur, la casa materna.

Quizás el anuncio de un trabajo infinito sobre Maquiavelo, en las cartas de 1859, sea la mejor noticia: la posibilidad de encarnar al Diablo sin Dios, la realización de un sacrificio maligno sin el peso de leyes inexorables. Pero

98 Julián Sauquillo, «Fascinación y terror ante la modernidad: Nietzsche, lector de Baudelaire», Nietzsche: modernidad y política (Raúl Sanz Burgos, Julián Sauquillo González, Francisco Serra Giménez), Madrid, Clásicos Dykinson, 2013, 149 págs., págs. 17-76.

99 Charles Baudelaire, «Edgar Poe, su vida y sus obras», Edgar Allan Poe, op. cit., págs. 61-63.

100 Théophile Gautier, «Baudelaire por Gautier», Baudelaire por Gautier, Gautier por Baudelaire, op. cit., págs. 37, 38.

101 Max Milner, Le Diable dans la littérature française de Cazotte a Baudelaire 1772-1861, Tomo II, Op Cit., pág. 408. 
el apremio a la madre con continuas peticiones económicas, y amparo y comprensión generales, expresan, más bien, una fatalidad diabólicasinsalvación posible («le guignon») (A Mme. Auspick, 23-XII-1865) ${ }^{102}$. La salvación es una eventualidad muy incierta: «[...]. Me encuentro medianamente mal, como estaré siempre. Intento, para disminuir todos mis males, trabajar regularmente. Cuando esto ocurra, seré el más grande y el más sereno de los hombres: estaré salvado.» (A Mme. Auspick, 22-VII-1856) ${ }^{103}$. Las preocupaciones editoriales en los periódicos, la ayuda a Jeanne Duval en caída abierta, las persistentes deudas, los domicilios cambiantes de un lugar a otro ${ }^{104}$ aplazan su deseo de constancia en el trabajo. Sólo pide: « $¡$ Un hueco! ¡ Un hueco! ¡ con tal de que esté limpio!» (A Mme. Auspick, 26-II-1958). Le asaltan las circunstancias sociales precarias que le impiden perseverar. Balzac llegó al talento -señalainsistiendo cada día en el trabajo. Pero este no es su caso. Supone: «en lo sucesivo no quiero confiar nada de mi vida al azar, pretendo que la voluntad la llene por completo» (A Mme. Auspick, 1-VII-1853) ${ }^{105}$. Los ruegos se vuelven cada vez más pobres: «Una jaula abierta a todos los ruidos» puede ser alivio de la holgazanería (A Mme. Auspick, 18-V-1854) ${ }^{106}$. «De pensión en pensión», ojalá no se viera en la humillación de que le digan: «¡Vaya! ¡Aun durmiendo!!» (A Mme. Auspick, 21-VII-1854) ${ }^{107}$. No es mal deseo expresar un: «voy a encerrarme herméticamente» (A Mme. Auspick, 28-VII-1854) 108 . Pero no es dueño de su tiempo: «¿Acaso no se da cuenta en qué conmoción $\mathrm{y}$ estremecimientos vivo, -que, a veces, no soy dueño de mi cabeza- y que no dispongo libremente de mi tiempo?» (A Mme. Auspick, 8-II-1857) ${ }^{109}$. Los reproches a Madame Auspick le atribuyen «humillaciones de todo género» y ruegan «caridad» y «reconciliación» (A Mme. Auspick, jueves, 20-XII$\left.1855^{110}\right)$. Si se diera «alguna tranquilidad», habría «un estallido de dinero»

102 Charles Baudelaire, Oeuvres completes, Correspondance generale Tomo V, op. cit., pág. 187.

103 Charles Baudelaire, Oeuvres completes, Correspondance generale, Tomo I, pág. 393

104 Sobre la continua erranza de Baudelaire por múltiples domicilios, Vid. Claude Pichois, Baudelaire a Paris (fotografías de Maurice Rué), París, Hachette, 1967, 31 págs.

105 Charles Baudelaire, Oeuvres completes, Correspondance generale (recogida, clasificada y anotada por Jacques Crepet), Tomo I, 1833-1856, op. cit. 442 págs., pág. 212. Una edición básica de las cartas a Madame Auspick: Baudelaire, Lettres à sa mère, París, l'école des loisirs, 1998, 229 págs..Una edición muy completa y con gran documentación: Charles Baudelaire, Cartas a la madre (1833-1866) (traducción, introducción y notas de Roberto Mansberger), Grijalbo-Mondadori, 1993, 376 págs. (traducción de la edición de Oeuvres completes, I-VII, París, Calmann-Levy Éditeurs, 1920).

106 Charles Baudelaire, Oeuvres completes, Correspondance generale, Tomo I, pág. 280.

107 Ibid., pág. 285.

108 Ibid. pág. 289.

109 Charles Baudelaire, Oeuvres completes, Correspondance generale, op. cit., Tomo II, op. cit. p.3.

110 Charles Baudelaire, Oeuvres completes, Correspondance generale, op. cit., Tomo I, 350, 351 
(A Mme. Auspick, 14-VIII-1854). Pero Baudelaire se lamenta de trabajar sin concentrarse, de aburrirse mortalmente, y de parecerle todo vacío. Sólo le estimula una «sed diabólica de goces, de gloria y de poder» (A Mme. Auspick, 4-XI-1856): «Hoy quiero ser una excepción -señala. Que se condecore a todos los franceses, excepto a mí» (A Mme. Auspick, 11-X-1860).

Baudelaire apenas logra trabajar ampliamente y con seguridad. Vagabundea y afronta todo tipo de contratiempos. No tiene forma de dedicarse a lo que determina su voluntad literaria. Los obstáculos son enormes pues escribe entre las querellas judiciales y los secuestros de chupatintas, de demócratas y napoleónicos. La soledad y el abatimiento cunden por el mal empleo del tiempo. Ya en 1857, se siente afectado por una enfermedad extraña a la medicina: «si alguna vez hubo enfermo, sin que su enfermedad fuese cosa de la medicina, ése, sin duda, soy yo.» (A Mme. Auspick, 25-XII-1857) ${ }^{111}$ Por entonces, el desaliento es inmenso, la desgracia se hace infinita. Le ahoga el aislamiento, la desconfianza hacia las propias fuerzas, la ausencia de deseos, la falta de distracción. La pobreza, los trastornos corporales, las deudas antiguas componen su particular infierno terrenal. El resultado es el «taedium vitae» antiguo o «spleen» moderno: «[...]. Me pregunto sin cesar: ¿y esto para qué? ¿y aquello para qué? Es el verdadero espíritu del spleen. [...].» (A Mme. Auspick, 30-XII-1857) ${ }^{112}$. Se encuentra acribillado por los problemas y preocupaciones. Sólo el éter y el opio calman los padecimientos corporales.

Pronto el deseo de redención a través del reconocimiento materno es un imperioso anhelo. Espera que su madre acumule todos los papeles (profesionales) que le envía. Toda virtud, resignación y valor le son pocos. Y los planes de trabajo en Honfleur le traen la esperanza de gloria y el afecto necesarios para la creación. El epistolario de Baudelaire con su madre Mme. Auspick- es el relato de una caída causada por el placer, la excitación permanente, el deseo de lujos y el ansia de viajes. Baudelaire admite el castigo cruel que recibe: «El mayor y único objeto de mi vida actual es trabajar, la cosa más dura y fastidiosa del mundo, la más agradable como hábito. Me considero un gran culpable que ha abusado de la vida, de mis facultades, de mi salud, como alguien que ha perdido veinte años soñando, lo que me coloca en inferioridad a una muchedumbre de animales que trabajan cada día.» (A Mme. Auspick, 25-XI-1863) ${ }^{113}$. Es culpable por indolencia. Pero, ¿acaso no cabe remontar la decadencia culpable? Pretendió superar la desconfianza cernida sobre él con una tutela judicial que le marcó para siempre. Quiere

111 Charles Baudelaire, Oeuvres completes, Correspondance generale, op. cit., Tomo II, op. cit., pág. 106.

112 Ibid.pág. 108.

113 Charles Baudelaire, Oeuvres completes, Correspondance generale, op. cit., Tomo IV, págs. 206, 207. 
ganar la dignidad que se le niega, remontar el estigma con que se le tacha. Amputada su libertad con la tutela de un notario, incapacitado legalmente, humillado, impotente, solitario, indolente, se ve imposibilitado para la gran obra que desea. Pero la escritura y el trabajo son la búsqueda de la salvación que no llega, en primer lugar, del público y, en segundo lugar, de su madre. Abandonado a su propia suerte, no renuncia a tener a Dios y a la fortuna de su lado ${ }^{114}$.

Baudelaire padece su desolación como una penitencia, por su dispendio pasado, ante el tribunal de su madre. Le parece cumplir una penitencia y acusa faltarle tiempo para redimir sus culpas en el escaso periodo de vida que, sabe, le queda. Le espanta la magnitud de todo lo que le queda por reparar. Le acucia su autorreproche por haber perdido el hábito de trabajo (A Mme, Auspick, 1-I1865, 3-II-1865, 11-II-1865, 3-IX-1865) ${ }^{115}$. Y, cuando le ahoga su desdicha, acelera su caída con su estancia de dos años en Bélgica ${ }^{116}$. Pobre Bélgica ${ }^{117}$ no podía ser publicado si permanecía en aquel país. Baudelaire era consciente. Se publicó mucho después de su muerte y convenientemente cercenado de su contenido más feroz con aquella población. Tales descalificaciones no pueden ser entendidas sino como una ruptura determinante con el infierno terrenal. Un sacrificio donde cumple su deseo de ser víctima y verdugo de una vez. Se desploma en la iglesia jesuita de Saint-Loup de Namur en Bélgica.

La invocación del poeta a un trabajo infinito sobre Maquiavelo es un deseo ardiente que no puede satisfacer. Hubiera encontrado a un Demonio pagano que, en esta ocasión, no coopera con Dios. El sacrificio de Maquiavelo, además, no encierra una autoinmolación. El consejero nunca hubiera escrito un Pobre Venecia, menos aún un Pobre Florencia. El florentino, consciente de la ductilidad de las masas, siempre aconsejó ser temido más que amado, pero era partidario de ser temido sin ser odiado ${ }^{118}$. Esa media distancia con la muchedumbre moderna es necesaria para irradiar una nueva Belleza ${ }^{119}$ -a la manera de los sueños de Poe- que no fracasara y se implantase en la

114 Ibid. pág. 273.

115 Charles Baudelaire, Oeuvres completes, Correspondance generale, op. cit., Tomo V, págs. 2, 3, 35, 36, 144, 188, 189.

116 Maurice Kunel, Baudelaire en Belgique, Bélgica, Editions Soledi, 1912 (nueva edición corregida y aumentada 1944), 209 págs.

117 La primera edición de esta obra es de 1953. Una edición mutilada: Pauvre Belgique (Jacques Crepet y Claude Pichois), París, Édition Louis Conard, 1953, 333 págs.. Una elemental edición se debe a Éric Lorio que destaca ser una obra inacabada del autor y se ocupa de ofrecerla mucho más inacabada de cómo quedó: Pauvre Belgique!, Belgica, ultraletters, 2016, 45 págs. La edición completada es: Charles Baudelaire, Pobre Bélgica (traducción de Luis Echávarri; introducción, revisión y notas de Américo Cristófalo y Hugo Savino), Buenos Aires, Losada, 1999, 242 págs..

118 Nicolás Maquiavelo, El príncipe, op. cit., pág. 107.

119 Charles Baudelaire, «Edgar Poe, su visa y sus obras», Edgar Allan Poe, op. cit., pág. 69. 
esfera de la ciudad. Investido de las máximas maquiavelianas, el poeta podría haberse erigido en Príncipe del Gusto de una época. Hubiera llegado a ser maquaveliano maquiavélico en vez de antimaquiaveliano maquiavélico como tantos católicos del Siglo de Oro español. Este maquiavelismo le hubiera saciado de goce. Le hubiera inculcado algún propósito edificativo para un supuesto hijo. El florentino le señala, así, a su hijo Guido, dulces consejos:

[...] es preciso que aprendas, y como ya no tienes la excusa de la enfermedad, esfuérzate por aprender las letras y la música, pues ves cuánto honor me hace a mí un poco de virtud que tengo; así que, hijo mío, si quieres contentarme a mí, y hacerte buen honor a ti mismo, haz el bien, aprende, que si tú te ayudas, todos te ayudaran. (A Guido Maquiavelo, Ímola, 2 de abril de 1527) ${ }^{120}$.

Baudelaire hubiera encontrado la ocasión de educar a un hijo que no tuvo. Entonces, hubiera podido plantearse no dejar a su descendencia la herencia de un imperio poético que, a su muerte, un hijo no pudiera defender por demasiado extenso $^{121}$. Pero basta, todos estos deseos son demasiados edificantes. Cabe decir, en favor del gran Charles Baudelaire, en el segundo centenario de su nacimiento, que, después de todo, no hay nada más hermoso y diabólico que un glorioso fracaso.

120 Nicolás Maquiavelo, Epistolario 1512-1527 (traducción, edición y notas de Stella Mastrangelo), México, Fondo de Cultura Económica, 1990, 557 págs., pág. 417.

121 Nicolás Maquiavelo, La vita di Castruccio Castracani da Lucca (introducción crítica de Riekie Brakkee, introducción y comentario de Paolo Trovato), Napolés, Liguori, 1986, 141 págs.. 